\title{
Design and Development of Management Information System in Ma'had Huffadz Bilingual Darul Hikmah Malang Using Scrum Method
}

\author{
Supriyono
}

\author{
Department of Informatics Engineering, Faculty of Science and Technology \\ Universitas Islam Negeri (UIN) Maulana Malik Ibrahim, Malang, Indonesia
}

\author{
priyono@ti.uin-malang.ac.id
}

\begin{abstract}
The scrum method is the most important thing in building software. The following research builds a management information system on Ma'had Huffadz Bilingual Darul Hikmah under Darus-Sa'adah Al Mardliyah Foundation. The institution, which is one of the Boarding Schools Tahfidzul Qur'an located in the city of Malang, East Java. The following research uses the Scrum framework. The implementation of the scrum method in the following research uses three sprints. The process of working on each sprint takes no more than a month. The software development in this research is web-based. Work on application programs using the Laravel framework using the PHP programming language. The results showed that the scrum method is very effective in building a boarding school management information system. Scrum is more dynamic, and the results of this scrum implementation can be seen from the system that has been developed. So that by implementing Scrum can produce a system that suits the requirements of the user.
\end{abstract}

Keywords: Effective, Scrum, Sprints, Requirements, Management information system

\section{Introduction}

Boarding Schools in Malang, East Java, according to the statistics of the Ministry of Religion 2019, amounted to 60 who have NSPP (Static Number Pondok Pesantren) both salaf huts and Koran huts with the number of students 6,889. In addition to the 60 boarding schools, there are many boarding schools and Ma'had that have not been officially registered either boarding schools for the public, students, or students. Based on the number of boarding schools shows that the interest in learning in boarding schools is quite high. Ma'had Huffadz Bilingual Darul Hikmah under Darus Sa'adah Al Mardliyah Foundation is one of the Pondok tahfidzul Qur'an located in Malang, East Java. This boarding school activity program focuses on memorizing AlQuran, but there are still other activities as supporting as well as reciting the book. The management in this cottage is still using the conventional way. As well as registration, payment, attendance activities, memorization monitoring, and reports are still done manually. The process of collecting, managing, and reporting data in all aspects in a boarding school that still uses manual means is considered less efficient and effective. Information System Development should look at some aspects of the need [1]. Confusion of processed data due to not being integrated can cause system failures [2][3].

Therefore in this study, researchers designed a management information system to overcome data confusion in Ma'had Huffadz Bilingual Darul Hikmah Malang by using scrum framework, which Scrum is part of agile software development. Scrum is a framework used to develop a complex product. In Scrum, the developers can solve complex problems and are also required to be able to produce high-value products. The characteristics of the Scrum framework are lightweight because Scrum can be easily implemented on a variety of issues, simple in framework implementation, Scrum stable and non-modifiable [4]. The Scrum method is very suitable for fast and effective software development [5]. In recent years, developments in the software development 


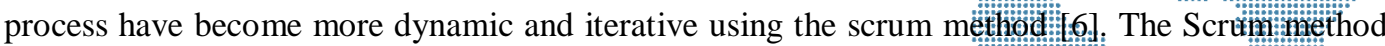
is a faster and more effective software development process than methods include design, development, testing, and review [8].

The stages of the scrum are as follows:

a. Product Backlog is a list or list of needs of a product. In this ease, the product owner plays a full role in determining the product backlog, including its content, availability, and order.

b. Scrum Planning is the stage of identifying the tasks of each team member. At this stage, it is very important because it determines the next process in running Sprint.

c. Sprint Backlog is the result of Scrum planning. The sprint backlog is a forecast from the development team regarding the functionality that will go into the next increment and the work that needs to be completed.

d. Sprint is a time limit that has a duration (one month or less). Sprint has a consistent period during the process of creating the system. Every Sprint done has been completed then continued on the next Sprint. Sprint consists of two (2) scrum daily and scrum sprint 30 days. Scrum daily is a daily meeting for approximately 15 minutes to evaluate the work, discuss obstacles during work, and make targets for the next job. While Scrum Sprint 30 days is a meeting conducted every month to discuss the product backlog that has been completed and evaluate to improve the work on the next Sprint.

e. Incremental software result is the result of the backlog product that has been completed on Sprint-Sprint, and the system can already be used. After the product is finished, then the next is Sprint review or submission of increments or results to the client. Which result of the product should be in a condition that can be used [9].

One of the modeling systems is to create Activity diagrams. The type of flowchart used to visually model the dynamic behavior of a particular part of a system that is most commonly used is activity diagrams [10]. The activity diagram shows the steps on the system work process created. The activity diagram serves to describe the order of activities in a system [11] .

\section{Research Methodology}

Scrum is part of agile software development, and Scrum is a framework used to develop a complex product. In Scrum, the developers can solve complex problems and are also required to be able to produce high-value products. The characteristics of the Scrum framework are lightweight because Scrum can be easily implemented on a variety of issues, simple in framework implementation, Scrum stable, and nonmodifiable.

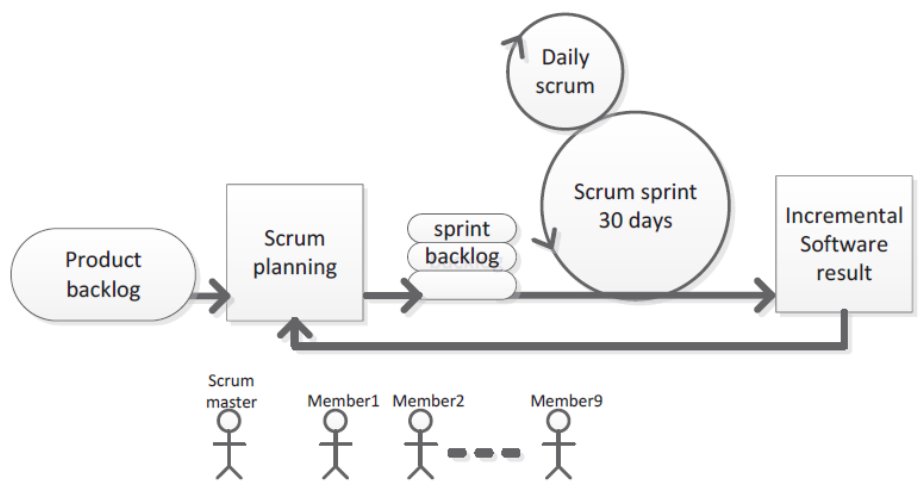

Figure 1. Scrum stage

Information System management of this integrated boarding school is a website-based system, the technology we use is as follows: 
$>$ Database

: MySql

$>$ Framework

: Laravel

Programming Language: PHP

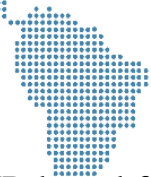

The process of creating it using the laravel framework is a PHP-based framework and has open-source properties [12]. This research uses the Scrum framewôrk, which consists of 3 Sprint-based product backlogs that have been created before [13]. Here's an explanation of each of his Sprints:

a. Sprint 1

Each Sprint consists of Scrum events, the following are the Scrum events in Sprint 1 :

\section{Sprint planning}

The results of the 1st Sprint design are:

Time : 3 weeks

Objective : initial design of the system

From Sprint planning generated the following Sprint backlog:

Table 1. Sprint backlog 1

\begin{tabular}{|c|c|c|c|}
\hline $\begin{array}{l}\text { Sprint } \\
\text { Stage }\end{array}$ & Assignment & Task Description & $\begin{array}{l}\text { Estimation } \\
\text { (Day) }\end{array}$ \\
\hline \multirow{8}{*}{ 1st Sprint } & \multirow{4}{*}{$\begin{array}{l}\text { Initial system } \\
\text { identification }\end{array}$} & Student activity process & 5 \\
\hline & & $\begin{array}{l}\text { The process of memorizing } \\
\text { students }\end{array}$ & \\
\hline & & Student payment process & \\
\hline & & Report process & \\
\hline & \multirow{3}{*}{$\begin{array}{l}\text { System } \\
\text { Concept } \\
\text { Design }\end{array}$} & Use case diagram & 10 \\
\hline & & Acitivity diagram & \\
\hline & & Design User Interface & \\
\hline & $\begin{array}{l}\text { Database } \\
\text { design }\end{array}$ & Create Database & 7 \\
\hline
\end{tabular}

\section{Daily Scrum}

Daily Scrum or scrum daily meeting at the time sprint is run to discuss what has been done and what will be done.

\section{Sprint Scrum 30 days}

Monthly meetings to discuss completed backlog products and can be an evaluation to improve work on the next Sprint.

b. Sprint 2

In each Sprint consists of Scrum event, here is scrum event on Sprint 2:

\section{Sprint planning}

The results of the 2nd Sprint design are:

Time : 4 weeks

Purpose : Create a master admin

From Sprint planning generated the following Sprint backlog:

Table 2. Sprint backlog 2

\begin{tabular}{|c|l|l|c|}
\hline $\begin{array}{c}\text { Sprint } \\
\text { Stage }\end{array}$ & Assignment & \multicolumn{1}{|c|}{ Task Description } & $\begin{array}{c}\text { Estimation } \\
\text { (Day) }\end{array}$ \\
\hline \multirow{3}{*}{ 2nd Sprint } & $\begin{array}{l}\text { Create a } \\
\text { landing page }\end{array}$ & $\begin{array}{l}\text { Create a landing page } \\
\text { before logging in to the } \\
\text { system }\end{array}$ & 7 \\
\cline { 2 - 5 } & Writing code & Create Login Feature for & 18 \\
\hline
\end{tabular}




\begin{tabular}{|c|c|c|c|}
\hline $\begin{array}{l}\text { Sprint } \\
\text { Stage }\end{array}$ & Assignment & Task Description & $\begin{array}{l}\text { Estimation } \\
\text { Est } \\
\text { (Day) }\end{array}$ \\
\hline & \multirow[t]{6}{*}{$\begin{array}{l}\text { for master } \\
\text { administrators }\end{array}$} & $\begin{array}{l}\text { some users, including } \\
\text { admins and students }\end{array}$ & \multirow[t]{6}{*}{ (") } \\
\hline & & Admin dashboard & \\
\hline & & $\begin{array}{lr}\text { Create user data } & \begin{array}{r}\text { features, } \\
\text { crud }\end{array} \\
\text { including } & \text { students, } \\
\text { administrators, } & \text { sturion } \\
\text { and verification of old } \\
\text { students. }\end{array}$ & \\
\hline & & $\begin{array}{l}\text { Create an activity } \\
\text { attendance feature }\end{array}$ & \\
\hline & & Create a payment feature & \\
\hline & & Create a report feature & \\
\hline
\end{tabular}

\section{Daily Scrum}

Daily Scrum or scrum daily meeting at the time sprint is run to discuss what has been done and what will be done.

\section{Sprint Srum 30 days}

Monthly meetings to discuss completed backlog products and can be an evaluation to improve work on the next Sprint.

c. Sprint 3

In each Sprint consists of Scrum event, here is scrum event on Sprint 3:

\section{Sprint planning}

The results of the design of the 3rd Sprint are:

Time : 4 weeks

Purpose : Create a system for the user

From Sprint planning generated the following Sprint backlog:

Table 3. Sprint backlog 3

\begin{tabular}{|c|l|l|c|}
\hline $\begin{array}{c}\text { Sprint } \\
\text { Stage }\end{array}$ & Assignment & \multicolumn{1}{|c|}{ Task Description } & $\begin{array}{c}\text { Estimation } \\
\text { (Day) }\end{array}$ \\
\hline & $\begin{array}{l}\text { Writing code } \\
\text { on the } \\
\text { system used } \\
\text { by the user }\end{array}$ & $\begin{array}{l}\text { Create registration forms } \\
\text { and Dashboards for system } \\
\text { students }\end{array}$ & \multicolumn{1}{|c|}{15} \\
\cline { 2 - 3 } 3rd Sprint & $\begin{array}{l}\text { Display licensing, } \\
\text { recitation, attendance, } \\
\text { penalties, and payment data }\end{array}$ & \\
\cline { 2 - 4 } & $\begin{array}{l}\text { Code writing } \\
\text { for internal } \\
\text { user } \\
\text { interfaces }\end{array}$ & $\begin{array}{l}\text { Create reports for internal } \\
\text { parties }\end{array}$ & \multirow{2}{*}{10} \\
\hline
\end{tabular}

\section{Daily Scrum}

Daily Scrum or scrum daily meeting at the time sprint is run to discuss what has been done and what will be done.

\section{Sprint Scrum 30 days}

The monthly meeting aims to discuss the completed product backlog and conduct evaluations for repair work on the next Sprint. 


\section{Results and Discussion}

The discussion in the following research includes the design and implementation of the system developed. The results of the creation of the diagram use ease can be stewn as shown in the following figure 2.

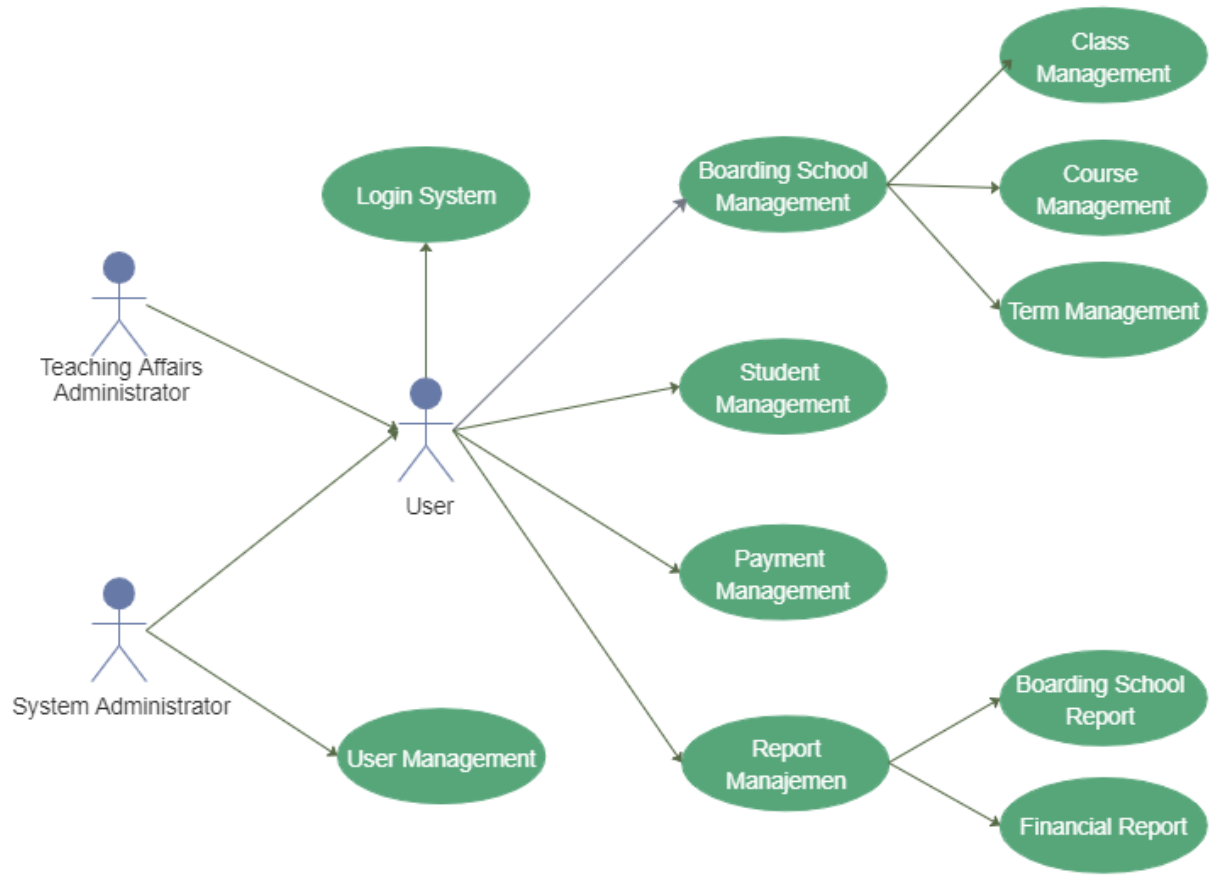

Figure 2. Use Case Diagram

The use case diagram consists of 3 actors, namely Teaching Affairs Administrator, User, System Administrator. The process described in the diagram use case includes Login System, Boarding School Management, User Management, Student Management, Payment Management, Report Manajemen, Class Management, Course Management, Term Management, Boarding School Report, Financial Report. The result of the implementation of the application program is shown in figure 3, 4 and 5.

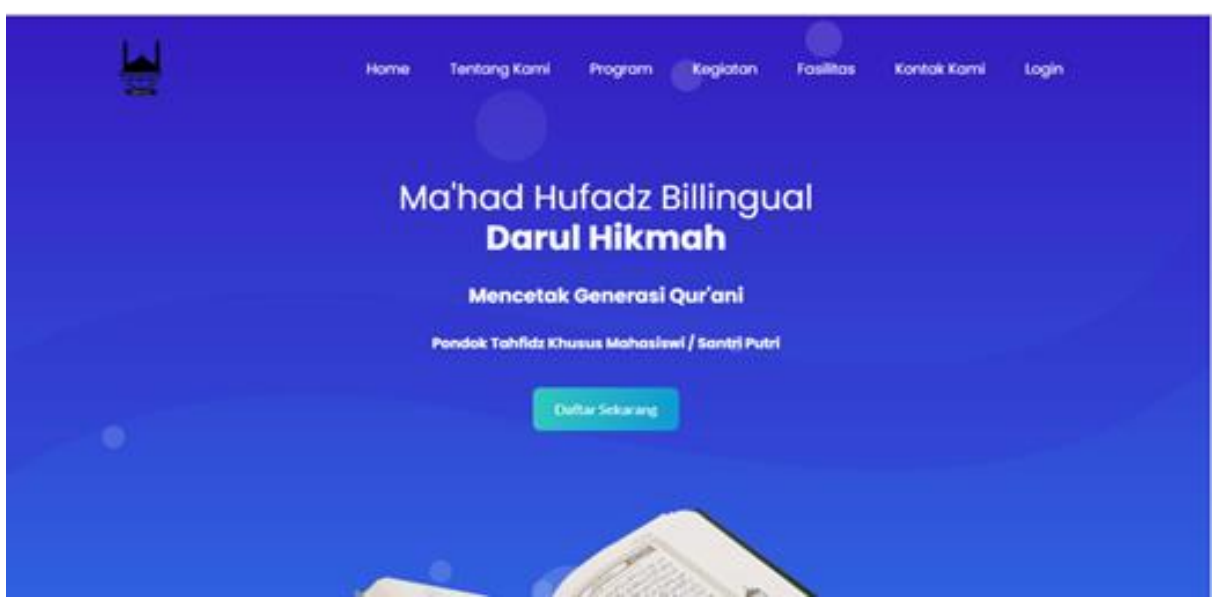

Figure 3. Menu View 
Figure 4. Report View

\subsection{Application Implementation Results.}

The assessment division uses the scale shown in table 4 and table 5 . The test involves relevant stakeholders so that software testing is obtained by covering several factors of software quality, including Correctness, Completeness, Consistency, Traceability, Reliability, Error Tolerance, Simplicity, Integrity, Usability, Operability, Access Control, and Communicativeness.

Tabel 4. Assessment Scale

\begin{tabular}{|l|c|}
\hline Description Assessment & Value \\
\hline Very Important & 0,8 \\
\hline Important & 0,7 \\
\hline Quite Important & 0,6 \\
\hline Not Important & 0,5 \\
\hline Very Inactive & 0,4 \\
\hline
\end{tabular}

Tabel 5. Software Testing

\begin{tabular}{|l|c|c|}
\hline \multicolumn{1}{|c|}{ Quality Factors } & Weight & Value \\
\hline Correctness & 0,8 & 4,1 \\
\hline Completeness & 0,7 & 4,0 \\
\hline Consistency & 0,8 & 4,5 \\
\hline Traceability & 0,6 & 4,2 \\
\hline Reliability & 0,8 & 4,0 \\
\hline Error Tolerance & 0,6 & 4,4 \\
\hline Simplicity & 0,7 & 4,3 \\
\hline Integrity & 0,8 & 4,6 \\
\hline Usability & 0,7 & 4,2 \\
\hline Operability & 0,7 & 4,3 \\
\hline Access Control & 0,6 & 4,4 \\
\hline Communicativeness & 0,7 & 4,4 \\
\hline
\end{tabular}




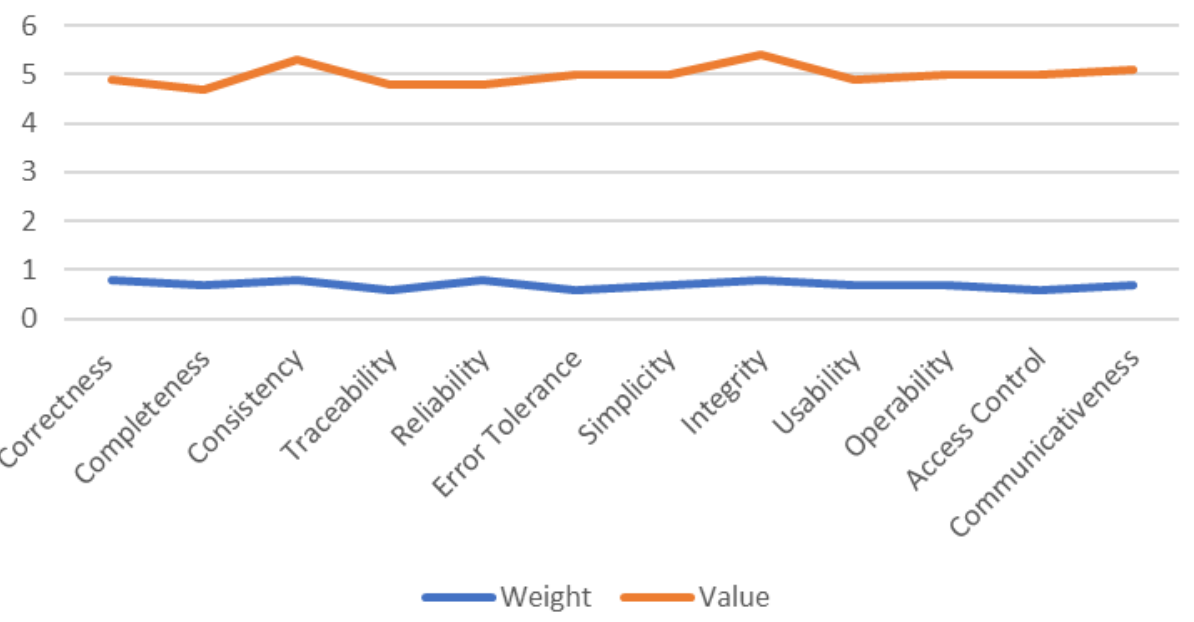

Figure 5. Software testing

\section{Conclusion}

The creation of an integrated boarding school management information system with the research object Ma'had Huffadz Bilingual Darul Hikmah uses a Scrum framework with 3 Sprints. At the same time, each Sprint has a different working period and task. The use of Scrum is more dynamic, and the results of this scrum implementation can be seen from the system that has been created. So by implementing Scrum can produce a system that suits your needs.

\section{References}

[1] M. Susilowati and A. A. Kusuma, "Software Requierement Specification Sistem Informasi Manajemen," SMARTICS J., vol. 5, no. 1, pp. 27-33, 2019, doi: 10.21067/smartics.v5i1.3444.

[2] S. Supriyono and S. Sutiah, "Improvement of Project Management Using Accelerated SAP Method in the Odoo ERP," pp. 1-9, 2020, doi: 10.4108/eai.3-82019.2290729.

[3] S. Supriyono and F. F. Maharani, "Analisis Kebutuhan Sistem Informasi Geografis Lahan Pertanian Sayuran dan Buah-buahan di Kota Batu," Matics, vol. 12, no. 1, p. 44, 2020, doi: 10.18860/mat.v12i1.8823.

[4] K. S. Haryana, "Penerapan Agile Development Methods Dengan Framework Scrum Pada Perancangan Perangkat Lunak Kehadiran Rapat Umum Berbasis QrCode," J. Comput. Bisnis, vol. 13, no. 2, pp. 70-79, 2020.

[5] Z. Ereiz and D. Music, "Scrum Without a Scrum Master," 2019 IEEE Int. Conf. Comput. Sci. Educ. Informatiz. CSEI 2019, pp. 325-328, 2019, doi: 10.1109/CSEI47661.2019.8938877.

[6] D. A. Barcelos Bica and C. A. G. Da Silva, "Learning process of agile scrum methodology with lego blocks in interactive academic games: Viewpoint of students," Rev. Iberoam. Tecnol. del Aprendiz., vol. 15, no. 2, pp. 95-104, 2020, doi: 10.1109/RITA.2020.2987721.

[7] N. Garzaniti, S. Briatore, C. Fortin, and A. Golkar, "Effectiveness of the Scrum Methodology for Agile Development of Space Hardware," IEEE Aerosp. Conf. Proc., vol. 2019-March, pp. 1-8, 2019, doi: 10.1109/AERO.2019.8741892.

[8] D. P. Kristiadi, F. Sudarto, D. Sugiarto, R. Sambera, H. L. H. S. Warnars, and K. Hashimoto, "Game Development with Scrum methodology," 2019 Int. Congr. Appl. Inf. Technol. AIT 2019, 2019, doi: 10.1109/AIT49014.2019.9144963. 


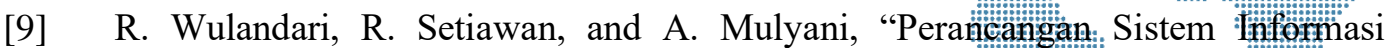

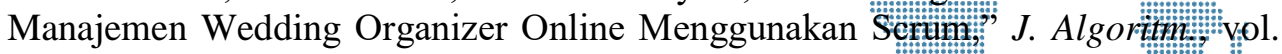
16, pp. 139-150, 2019.

[10] L. R. A. Daniel R. Windle, Software Requirements Using Practical Approach. 2003.

[11] Supriyono and M. Faisal, "Dynamic Monitoring and Assessment for Digital Transformation in Higher Education," Proc. Int. Conf. Eng. Technol. Soc. Sci. (ICONETOS 2020), vol. 529, no. Iconetos 2020, pp. 1-7, 2021, doi: 10.2991/assehr.k.210421.001.

[12] D. Mediana, "Rancang Bangun Aplikasi Helpdesk (A-Desk) Berbasis Web Menggunakan Framework Laravel ( Studi Kasus di PDAM Surya Sembada Kota Surabaya )," J. Manaj. Inform., vol. 8, no. 2, pp. 75-81, 2018.

[13] S. Hartono, R. Tjahyadi, and C. Cassandra, "Analysis of Trouble Ticket System Using COBIT 5 Framework (A Case Study Approach)," Proc. 2019 Int. Conf. Inf. Manag. Technol. ICIMTech 2019, vol. 1, no. August, pp. 420-425, 2019, doi: 10.1109/ICIMTech.2019.8843709.

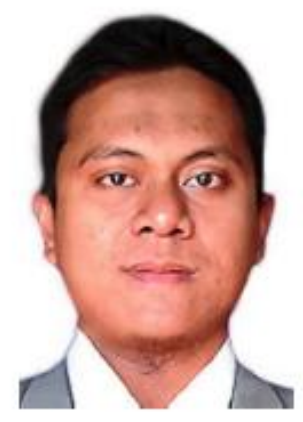

\section{Authors}

Supriyono, S.Kom., M.Kom Education that has been taken in the Department of Computer science at Universitas Brawijaya Malang and the Magister Program of Informatics Engineering of Institut Teknologi 10 Nopember Surabaya in the field of software engineering. Currently, the Lecturer majoring in the Department of Informatics Engineering at Universitas Islam Negeri (UIN) Maulana Malik Ibrahim Malang. Current research is related to system needs engineering, software quality, software management, and software development using several methods applied as well as in general, the research conducted in the centration in the field of software engineering. 